\title{
A Conceptual Model for Agility Strategy and Work Organization by Structural Equation Modeling: A Case Study in the Iranian Textile Industry
}

\author{
Hossein Safari (Corresponding author) \\ Associated Professor, Faculty of management \\ University of Tehran, Tehran, Iran \\ E-mail: hsafari@ut.ac.ir \\ Samira Maghsoudi \\ M.S. of Industrial Management \\ University of Tehran, Tehran, Iran \\ Tahereh Keshavarzi \\ M.S. Candidate of business Management \\ University of Tehran, Tehran, Iran
}

\begin{abstract}
Amirhesam Behrooz
M.S. Candidate of Executive Management of Business Administration

University of Tehran
\end{abstract}

Received: March 29, 2013 Accepted: April 14, 2013

doi:10.5296/ber.v3i1.3446 URL: http://dx.doi.org/10.5296/ber.v3i1.3446

\begin{abstract}
Agile manufacturing is a new concept in manufacturing intended to improve the competitiveness of firms. Recent studies assert that agility has serious association with the
\end{abstract}


work organization. The aim of this paper, is presenting a conceptual model for Agility Strategy (AS) and Work Organization (WO) in the Iranian Textile Industry.

In this study, after reviewing the related literature; firstly, the effective factors in the AS and WO was identified. Secondly, questionnaires were distributed among five Iranian textile company's experts. Then, 195 filled questionnaires were collected. Next, Factor Analysis and Structural Equation Modeling were used to discover the relation between AS and WO; as a result, the proposed model was extracted. Our findings show that there is the significant and positive relationship between AS and WO in the Iranian Textile Industry.

Keywords: Agility Strategy (AS), Work Organization (WO), Structural Equation Modelling (SEM), the Iranian Textile Industry

\section{Introduction}

Textile industry is perhaps one of the biggest and most influential industries in the world and is attracting big economies with its extremely high cash flow. Textile industry is a fundamental aspect of any society due to the need for people to use clothing, footwear, etc. The main reason for textile's importance is the fact that most of the countries invest in textile to industrialize and develop their economies with China as a good example. India and Pakistan have about $30 \%$ of their workforce employed in textile and clothing industries. Since textile industry is labor intensive, it plays an important role in increasing employment rate and it can be a strategically viable plan to fight unemployment in countries. It seems that Agility is necessity in manufacturing organizations especially in textile industry with the highest rate of employment in Iran.

Agility represents a new approach to manufacturing and management, which is very different from a planned mass production. It was first introduced officially to the public in 1991 by Iacocca Research Institute in Lehigh University in a report called "the strategy of manufacturing firms in 21st century: the viewpoint of industrial specialists" (Yaghoubi and Rahat Dahmardeh, 2010).

Agile manufacturing is a new concept in manufacturing intended to improve the competitiveness of firms. Manufacturing processes based on agile manufacturing are characterized by customer-supplier integrated process for product design, manufacturing marketing, and support services (Gunasekaran, 1999).

There is a significant difference in understanding of terms, flexibility and agility, if they are referred to the manufacturing strategy. Thus agile manufacturing can be considered as a manufacturing strategy that is different from the flexible, lean manufacturing, and other strategies and techniques (Sherehiy et al., 2007).

Yaghoubi and Rahat Dahmardeh (2010) proposed that the best and newest way of survival and success of the organizations is focusing on their organizational agility, and the organizational agility is a wisely and complete response to the rapidly changing requirements in competitive markets and succeeding by the opportunities the organization gets.

Today's enterprises operate in extremely competitive environment of a global market. The 
increased rate of innovation and technological developments, fragmentation of markets and elevated customer expectations towards customized products lead to the especially turbulent and rapid changes in the business environment. The problem how organizations can successfully deal with an unpredictable and constantly changing environment has been a prevailing topic both in industry and academia for a few decades. Many different solutions were proposed: networking, reengineering, modular organizations, virtual corporations, high performing organizations, employee empowerment, flexible manufacturing, just-in-time, etc... Among proposals of how to deal with the uncertain and unpredictable environment the notion of agility is the most predominant and popular lately. This concept was proposed to describe a new approach in manufacturing and enterprise management that is necessary to achieve success in a modern dynamically changing market (Sherehiy, 2008). In this study the agility, the ability of an organization to respond quickly to the changes in the internal and external business environment and to act proactively referring to the changes to achieve the opportunities that occur due to change is defined.

Recent studies assert that agility has serious association with the work organization (Plonka, 1997; Parker and wall, 1998). It is expected that work in an agile company will become more complex due to use of advanced manufacturing and information technologies. Since agility needs quickly response to market changes, this leads to increased uncertainty in the work environment and requires the employees' constant adaption to new needs, circumstances, changes in work processes, and technologies. In addition, flexible technologies resulting in increased operational uncertainty due to more variability and complexity in work processes (Parker et al., 2001).

The aim of this paper is "investigating interactions between indicators Agility Strategy (AS) and WO in the Iranian Textile Industry". This study was using second source data and case study. First we studied literature of AS, WO, and searches about AS's impact on different aspects of a company. After reviewing the literature and identification of indicators, a questionnaire between experts was distributed and 195 questionnaires were completed. At the end we utilized structural equation modeling (SEM) by Lisrel 8.5 software and analysis output was published. By performing this research, we hope that some light is shed on the relationship between AS and WO in textile industry.

\section{Previous Research}

\subsection{Agility Strategy (AS)}

Here, agility is considered as a strategy that combines different methods, techniques and developed ideas in flexible organization and this may lead to the use of different manufacturing strategies based on the needs of a current situation in a business environment. Five principal agile sub-strategies, necessary to achieve agility, are specified in the literature : 1) product related agility; 2) cooperation related agility; 3) organization related change capabilities; 4) manufacturing agility; 5) people and knowledge related change capabilities (Sherehiy, 2008; Jackson and Johansson, 2003; Goldman et al., 1995). In Table 1 there is a short review of researches about Agility Strategy dimensions. 


\section{MInstitute ${ }^{\text {Mink }}$}

Business and Economic Research

ISSN 2162-4860

2013, Vol. 3, No. 1

Table 1. A review of Agility Strategy key dimensions

\begin{tabular}{|c|l|}
\hline $\begin{array}{c}\text { Key } \\
\text { dimensions }\end{array}$ & \multicolumn{1}{c|}{ Author(s) } \\
\hline Product (P) & $\begin{array}{l}\text { (Sherehiy, 2008), (Lin et al., 2006), (Jackson and Johansson, 2003), (Tsourveloudis and Valavanis, } \\
\text { 2002), (Yusuf and Adeleye, 2002), (Sharifi and Zhang, 1999), (Yusuf et al., 1999), (Goldman et al., } \\
\text { 1995). }\end{array}$ \\
\hline $\begin{array}{c}\text { Organization } \\
\text { (Org) }\end{array}$ & $\begin{array}{l}\text { (Sumukadas and Sawhney, 2004), (Arteta and Giachetti, 2004), (Jackson and Johansson, 2003), } \\
\text { 1995). }\end{array}$ \\
\hline $\begin{array}{c}\text { Cooperation } \\
\text { (CO) }\end{array}$ & $\begin{array}{l}\text { (Sherehiy, 2008), (Lin et al., 2006), (Sumukadas and Sawhney, 2004), (Jackson and Johansson, 2003), } \\
\text { (Sharifi and Zhang, 1999), (Kathuria and Partovi, 1999). }\end{array}$ \\
\hline $\begin{array}{c}\text { People (PE) } \\
\text { (Sumukadas and Sawhney, 2004), (Jackson and Johansson, 2003), (Kathuria and Partovi, 1999), } \\
\text { (Sharifi and Zhang, 1999), (Goldman et al., 1995), (Yusuf et al., 1999). }\end{array}$ \\
\hline
\end{tabular}

\subsection{AS's Dimensions}

We define different dimensions in AS operationally that is collected from literature study.

\subsubsection{Product $(\mathrm{P})$}

Goldman et al. (1995) proposed that here product means bringing products to the market as quickly and cost efficiently as possible and also means providing value and solutions to the customer. This dimension is related to the product strategies and operations needed to respond to market change and uncertainty (Jackson and Johansson, 2003).

\subsubsection{Organization (Org)}

Effective controlling of changes requires flexible organizational structures which allow fast re-shaping the physical and human resources provides (Goldman et al., 1995). The competency of change in operations is concerned with methods, competencies, and tools needed to manage long and short term changes in the production systems (Jackson and Johansson, 2003).

\subsubsection{Cooperation (Co)}

According to Goldman et al. (1995), cooperation means cooperate internally and with other companies. Cooperation refers to the ability of company departments to cooperate among them and the ability of company to cooperate with suppliers and customers (Jackson and Johansson, 2003).

\subsubsection{People (Pe)}

An agile competitive environment is where the people skills, experience, and knowledge are the main differences between the companies. Thus, the permanent work force, training and education are integral factors to an agile enterprise's operations and indicate an investment into future success (Goldman et al., 1995). This dimension relates to the need for placement of knowledge and ability of employees as a basis of all operations that are faced with turbulent market changes (Jackson and Johansson, 2003).

\subsection{Work Organization (WO)}

Several theories have offered explanations regarding work characteristics that have important 


\section{Ml Macrothink}

Business and Economic Research ISSN 2162-4860 2013, Vol. 3, No. 1

influence on the employees' performance (Sherehiy, 2008). Some authors identified that The Job Characteristic Model is the most widely applied and dominant approach for research on job design and work customs. Although some aspects of this model have not been confirmed by empirical research, the job characteristics which are defined have been found to be related to wide range of the work outcomes (Morgeson and Campion, 2003; Parker and Wall, 1998; Wall and Martin, 1987). In Table 2 there is a short review of researches about Work Organization dimensions.

Table 2. A review of Work Organization key dimensions

\begin{tabular}{|c|c|}
\hline Key dimensions & \multicolumn{1}{c|}{ Author(s) } \\
\hline $\begin{array}{c}\text { Job uncertainty } \\
\text { (JUN) }\end{array}$ & (Pulakos et al., 2002), (Allworth and Hesketh, 1999). \\
\hline $\begin{array}{c}\text { Job complexity } \\
\text { (JCM) }\end{array}$ & (Ohly et al., 2006), (Pulakos et al., 2002), (Fay and Frese, 2001), (Frese et al., 1998). \\
\hline $\begin{array}{c}\text { Job demands } \\
\text { (JDM) }\end{array}$ & (Sherehiy, 2008), (Pulakos et al., 2002), (Plonka, 1997). \\
\hline $\begin{array}{c}\text { Job control (JC) } \\
\text { (Yusuf et al., 1999), (Kathuria and Partovi, 1999), (Plonka, 1997), (Karasek and Theorell, 1990), } \\
\text { (Walton and Susman, 1987), (Dawis and Lofquist, 1984). }\end{array}$ \\
\hline $\begin{array}{c}\text { Skill variety (SV) } \\
\text { (Pulakos et al., 2002), (Plonka, 1997), (Karasek, 1979), (Forsythe, 1997), (Karasek and Theorell, } \\
\text { 1990), (Hackman and Oldham, 1975). }\end{array}$ \\
\hline
\end{tabular}

\subsection{WO's Dimensions}

We define different dimensions in AS operationally that is collected from literature study.

\subsubsection{Job Uncertainty (JUN)}

Job uncertainty refers to the extent the job is unpredictable and presents employee with surprising and unpredictable situations (Sherehiy, 2008).

\subsubsection{Job Complexity (JCM)}

Job complexity dimension describes the extent to which the job is complex and difficult to perform (Sherehiy, 2008).

\subsubsection{Job Demands (JDM)}

The job demands dimension refers to the cognitive and physical effort that an employee has to exert in order to successfully perform a job (Sherehiy, 2008). According to Karasek (1979), Job demands mean the demands of work situation.

\subsubsection{Job Control (JC)}

The job control dimension indicates the degree of freedom and independence an employee has in scheduling work and deciding how to perform the work (Sherehiy, 2008). The job control provides a range of control employees have over the certain aspect of the task performance, likes the way they apply and the order in which they manage their tasks (Karasek, 1979).

\subsubsection{Skill Variety (SV)}

According to Hackman and Oldham (1975), skill variety refers to the extent to which the job 


\section{Macrothink}

Business and Economic Research ISSN 2162-4860 2013, Vol. 3, No. 1

needs to perform a tasks variety and use wide range of employee's skills and abilities. Skill variety describes the degree to which workers have control over the use of their skills (Karasek, 1979).

\subsection{Structural Equation Modeling (SEM)}

SEM is a comprehensive statistical approach to testing hypotheses about relations among observed and latent variables. A major advantage of SEM is the ability to estimate a complete model incorporating both measurement and structural considerations. We tested the measurement and research models by applying a structural equation modeling (SEM) approach, using the computer software program LISREL 8.5 with 195 samples. We used a variety of indices to evaluate model fit. The seven fit indices used and values indicating acceptable model fit include:

1. The ratio of the $\chi^{2}$ statistic to its degrees of freedom, with values of less than 3 indicating acceptable fit;

2. Root mean squared error of approximation (RMSEA), with values below 0.08 representing acceptable fit;

3. Goodness of fit index (GFI), with values exceeding 0.9 indicating good fit;

4. Adjusted GFI (AGFI), with values exceeding 0.8 indicating acceptable fit (Ngai et al., 2007).

\section{Hypotheses and Proposed Model}

This Proposed model is composed of two kinds of variables: Agility Strategy (AS) and Work Organization (WO). The conceptual model incorporating the research hypotheses is shown in the following figure.

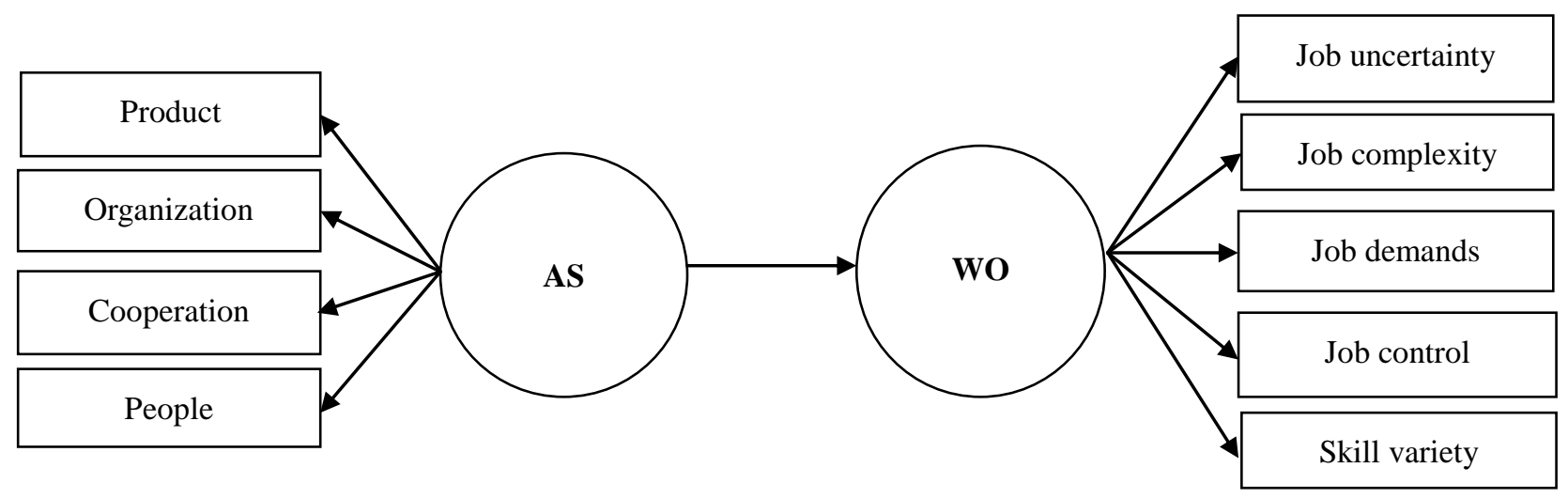

Figure1. Research proposed model

According to the above-mentioned figure research main hypothesis is:

H1: AS will positively influence WO meaningfully.

And Research Sub hypothesizes are: 


\section{Mll Macrothink}

Business and Economic Research ISSN 2162-4860 2013, Vol. 3, No. 1

H2: AS is defined as a higher-order construct which represents (a) Product, (b) Organization, (c) Cooperation and (d) People.

H3: WO is defined as a higher-order construct which represents (a) Job uncertainty, (b) Job complexity, (c) Job demands, (d) Job control and (e) Skill variety.

\section{Research Methodology}

\subsection{Research Method}

Research method is used for this article is descriptive-correlation. This study was using second source (library and other recorded observations) data and case study. First we studied literature of AS, WO, SEM, and researches about AS's impact on different aspects of a company. Criteria were extracted and we distributed questionnaires between experts and professionals in five companies in the Iranian Textile Industry and 195 filled questionnaires were gathered. At the end we utilize structural equation modeling (SEM) by Lisrel 8.5 software and analysis output was published.

\subsection{Statistical Population and Sample Size}

The formal survey was conducted based on the preliminary survey and the duration is approximately four months, from September 2010 to December 2010. Statistical population in this research is including Industrial Experts in five companies in the Iranian Textile Industry and composed of three management levels (Operational managers, Middle managers and Top managers). There were 400 Experts in these five companies.

With regard to population, sample size was determined and it was about 196 persons. We used random classified sampling for this research. Table 3 is illustrating the ratio of this groups and sample sizes. After distribution of 300 questionnaires with an overall response rate of $65 \%$; we could gather 195 filled questionnaires from experts. Participants were informed of the main objective of the study, and also were presented with a written definition of keywords to build shared concept. They were encouraged to sincerely respond to all the questions in the questionnaire and were assured of absolute anonymity.

Table 3. Population and sample size in 5 companies in the Iranian Textile Industry

\begin{tabular}{|c|c|c|c|c|c|c|}
\hline Company & $\begin{array}{c}\text { Laleh Mehregan } \\
\text { Textile }\end{array}$ & $\begin{array}{c}\text { Negin } \\
\text { Carpet }\end{array}$ & $\begin{array}{c}\text { Mashhad } \\
\text { Carpet }\end{array}$ & $\begin{array}{c}\text { Mashhad } \\
\text { Leather }\end{array}$ & $\begin{array}{c}\text { Mashhad } \\
\text { Spinning }\end{array}$ & Total \\
\hline $\begin{array}{c}\text { Population } \\
\text { size }\end{array}$ & 59 & 88 & 121 & 83 & 49 & 400 \\
\hline $\begin{array}{c}\% \text { in } \\
\text { population }\end{array}$ & $14.75 \%$ & $22 \%$ & $30.25 \%$ & $20.75 \%$ & $12.25 \%$ & $100 \%$ \\
\hline Sample size & 28 & 47 & 56 & 36 & 28 & 195 \\
\hline$\%$ in sample & $14.36 \%$ & $24.1 \%$ & $28.72 \%$ & $18.46 \%$ & $14.36 \%$ & $100 \%$ \\
\hline
\end{tabular}

\subsection{Information Gathering Tools}

Implemented questionnaires are composed of two parts: 21 questions about AS's dimensions make the first part, Product (with 8 questions), Organization (with 5 questions), and "Cooperation" and "People" (with 4 questions each). Second part was about WO that contained 11 questions about Job uncertainty, Job complexity, Job control, and Skill variety 
(with 2 questions each) and Job demands (with 3 questions).

\subsection{Reliability and Validity}

\subsubsection{Reliability}

The summary statistics of formal survey are shown in Table 4. For reliability evaluation we utilized Cronbach's alpha. The Cronbach's alpha reliability of all the ten latent variables are more than $0.6(\alpha>0.6)$, which indicates all scales demonstrate good reliability.

Table 4. The summary statistics of formal survey

\begin{tabular}{|c|c|c|c|c|}
\hline instrument & $\mathrm{N}$ & Mean & SD & $\alpha$ \\
\hline Product (P) & 8 & 2.4603 & 0.9747 & 0.929 \\
\hline Organization (Org) & 5 & 3.1713 & 1.1891 & 0.886 \\
\hline Cooperation (Co) & 4 & 3.0205 & 1.2025 & 0.856 \\
\hline People (Pe) & 4 & 2.4269 & 1.0195 & 0.862 \\
\hline AS & 21 & $\ldots \ldots$ & $\ldots \ldots$ & 0.949 \\
\hline $\begin{array}{c}\text { Job uncertainty } \\
\text { (JUN) }\end{array}$ & 2 & 3.4688 & 1.2497 & 0.817 \\
\hline $\begin{array}{c}\text { Job complexity } \\
\text { (JCM) }\end{array}$ & 2 & 3.4762 & 1.3063 & 0.817 \\
\hline \begin{tabular}{c} 
Job demands (JDM) \\
\hline $\begin{array}{c}\text { Job control (JC) } \\
\text { Skill variety (SV) }\end{array}$
\end{tabular} & 2 & 3.2503 & 1.0966 & 0.741 \\
\hline WO & 11 & $\ldots \ldots$ & $\ldots \ldots$ & 0.847 \\
\hline Total & 32 & $\ldots \ldots$ & $\ldots \ldots$ & 0.913 \\
\hline
\end{tabular}

$\mathrm{N}=$ Number of questions (items), $\mathrm{SD}=$ standard deviation; $\alpha=$ Cronbach's alpha coefficient.

\subsubsection{Validity}

For evaluating validity of questionnaires, we used content validity and construct validity.

\subsubsection{Content Validity}

Content validity deals with how representative and comprehensive the items were in creating the scale. It is assessed by examining the process by which scale items are generated (Moon and Kim, 2001). Content validity assured us that all aspects and parameters that impact on main content were evaluated. For testing content validity after devising a framework for questionnaire, we asked 30 experts to modify it if needed. These experts evaluated all implemented criteria in questionnaire and modified it.

\subsubsection{Construct validity}

Construct validity determines the extent to which a scale measures a variable of interest (Moon and Kim, 2001). In this research we used factor analysis for considering the structure of 


\section{MInstitute Macrothink $_{\text {Int }}$}

Business and Economic Research ISSN 2162-4860 2013, Vol. 3, No. 1

research. Exploring factor analysis and criteria factor was used to investigate construction of questionnaire. Factor analysis depicted that all mentioned criteria are measured in these questionnaires.

\section{Data Analysis}

Data analysis is accomplished by inferential statistics techniques particularly exploratory factor analysis and confirmatory factor analysis. In this section 21 variables related to AS and 11 variables related to WO are factored through factor analysis method. Results shown in Tables 5 to 6 .

The relationships between variables are identified using exploratory factor analysis and then the factoring is implemented. The result is applied in structural equation modeling (SEM) used in confirmatory factor analysis. The variables are properly factored during the exploratory factor analysis. Through confirmatory factor analysis in structural equation modeling (SEM) factoring is either accepted or rejected. The software SPSS 18.0 is applied for first analysis and Lisrel 8.53 is applied for the second. In the following sections the results of exploratory factor analysis and after that the results of SEM are presented. The secondary hypothesis, that is H2 and H3, are studied. Finally the main hypothesis is explained after the confirmatory factor analysis of both sides of the model separately. In fact we have tested our proposed model in three steps: 1.AS: its latents and indicators; 2.WO: its latents and indicators; and, 3.The effect of AS on WO.

\subsection{The Results of Exploring Factor Analysis}

\subsubsection{Exploring factor analysis result of AS's questionnaire}

We considered 21 questions by factor analysis and based on 195 gathered questionnaires; KMO was 0.882 showing that the sample size was enough. Also considering the fact that sig. in Bartlett test was lower than 0.05. The Total Variance Explained for the seven factors in the questionnaire was found to be $72.67 \%$, which explains the variance of the concept of AS, in fact indicating a high level of reliability for the questionnaire. The result of Exploratory Factor Analysis for the AS model has been shown in Table 5.

Table 5. Rotated Component Matrix for the AS model

\begin{tabular}{|c|c|c|c|c|}
\hline \multirow{2}{*}{ questioners } & \multicolumn{4}{|c|}{ Component } \\
\cline { 2 - 5 } & Product (P) & $\begin{array}{c}\text { Organization } \\
(\text { Org })\end{array}$ & $\begin{array}{c}\text { People } \\
(\text { Pe })\end{array}$ & $\begin{array}{c}\text { Cooperation } \\
(\text { Co })\end{array}$ \\
\hline P1 & .557 & .319 & .488 & .139 \\
\hline P2 & .646 & .474 & .069 & .212 \\
\hline P3 & .724 & .220 & .197 & .305 \\
\hline P4 & .597 & .287 & .195 & .366 \\
\hline P5 & .821 & .206 & .279 & .111 \\
\hline P6 & .728 & .250 & .382 & .161 \\
\hline P7 & .625 & .446 & .319 & .147 \\
\hline P8 & .730 & .137 & .177 & .341 \\
\hline ORG1 & .185 & .777 & .233 & .249 \\
\hline ORG2 & .299 & .695 & .312 & .068 \\
\hline ORG3 & .487 & .778 & .180 & \\
\hline
\end{tabular}




\begin{tabular}{|c|c|c|c|c|}
\hline ORG4 & .587 & .531 & .125 & .252 \\
\hline ORG5 & .108 & .795 & .061 & .183 \\
\hline CO1 & .409 & .146 & .243 & .672 \\
\hline CO2 & .076 & .037 & .151 & .876 \\
\hline CO3 & .211 & .310 & .216 & .732 \\
\hline CO4 & .374 & .152 & .133 & .710 \\
\hline PE1 & .323 & .178 & .755 & .137 \\
\hline PE2 & .556 & -.026 & .582 & .343 \\
\hline PE3 & .239 & .143 & .792 & .178 \\
\hline PE4 & .106 & .310 & .780 & .245 \\
\hline
\end{tabular}

5.1.2 Exploring factor analysis result of WO's questionnaire

We considered 11 questions by factor analysis and based on 195 gathered questionnaires; KMO was 0.791 showing that the sample size was enough. Also considering the fact that sig. in Bartlett test was lower than 0.05. The Total Variance Explained for the four factors in the questionnaire was found to be $80.01 \%$, which explains the variance of the concept of WO, in fact indicating a high level of reliability for the questionnaire. The result of Exploratory Factor Analysis for the WO model has been shown in Table 6 .

Table 6. Rotated Component Matrix for the WO model

\begin{tabular}{|c|c|c|c|c|c|}
\hline \multirow{3}{*}{ questioners } & \multicolumn{5}{|c|}{ Component } \\
\cline { 2 - 6 } & $\begin{array}{c}\text { Job } \\
\text { Demands } \\
\text { (JDM) }\end{array}$ & $\begin{array}{c}\text { Job } \\
\text { Contro } \\
\text { (JC) }\end{array}$ & $\begin{array}{c}\text { Job } \\
\text { Uncertainty } \\
(\text { JUN) }\end{array}$ & $\begin{array}{c}\text { Job } \\
\text { Complexity } \\
\text { (JCM) }\end{array}$ & $\begin{array}{c}\text { Skill } \\
\text { Variety } \\
\text { (SV) }\end{array}$ \\
\hline JUN1 & .107 & .170 & .863 & .240 & .111 \\
\hline JUN2 & .079 & .273 & .825 & .255 & .081 \\
\hline JCM1 & .139 & .149 & .210 & .857 & .216 \\
\hline JCM2 & .178 & .219 & .341 & .804 & .059 \\
\hline JDM1 & .750 & .214 &. .008 & .085 & .234 \\
\hline JDM2 & .813 & .266 & .074 & .109 & .340 \\
\hline JDM3 & .762 & -.178 & .205 & .173 & .097 \\
\hline JC1 & .153 & .825 & .304 & .176 & .142 \\
\hline JC2 & .140 & .889 & .160 & .140 & .802 \\
\hline SV1 & .149 & .089 & .091 & .080 & .846 \\
\hline SV2 & .109 & .114 & .067 & & \\
\hline
\end{tabular}

\subsection{The Results of Confirmatory Factor Analysis}

\subsubsection{X model; Measurement Model of AS}

In the initial step we applied confirmatory factor analysis in Lisrel 8.5 and eventually conducted path diagram of X model as per Figure 2. We have tested relationship between AS latent and its indicators. Fitness's indices in Table 7 shows good fitness of our X model, proving selected indicator are good representative for each dimension of AS. Also AS is defined as a higher-order construct which represents (a) Product, (b) Organization, (c) Cooperation and (d) People. So our second hypothesis (H2) is supported. 


\section{Macrothink}

Table 7. AS model fitness indices

\begin{tabular}{|c|c|}
\hline fitness indices & $\begin{array}{c}\text { Measure of } \\
\text { Index }\end{array}$ \\
\hline Chi-Square/df & 1.9267 \\
\hline P-value & 0.000 \\
\hline $\begin{array}{c}\text { Root Mean Square Error of } \\
\text { Approximation (RMSEA) }\end{array}$ & 0.037 \\
\hline Goodness of Fit Index (GFI) & 0.94 \\
\hline Adjusted Goodness of Fit Index (AGFI) & 0.92 \\
\hline
\end{tabular}

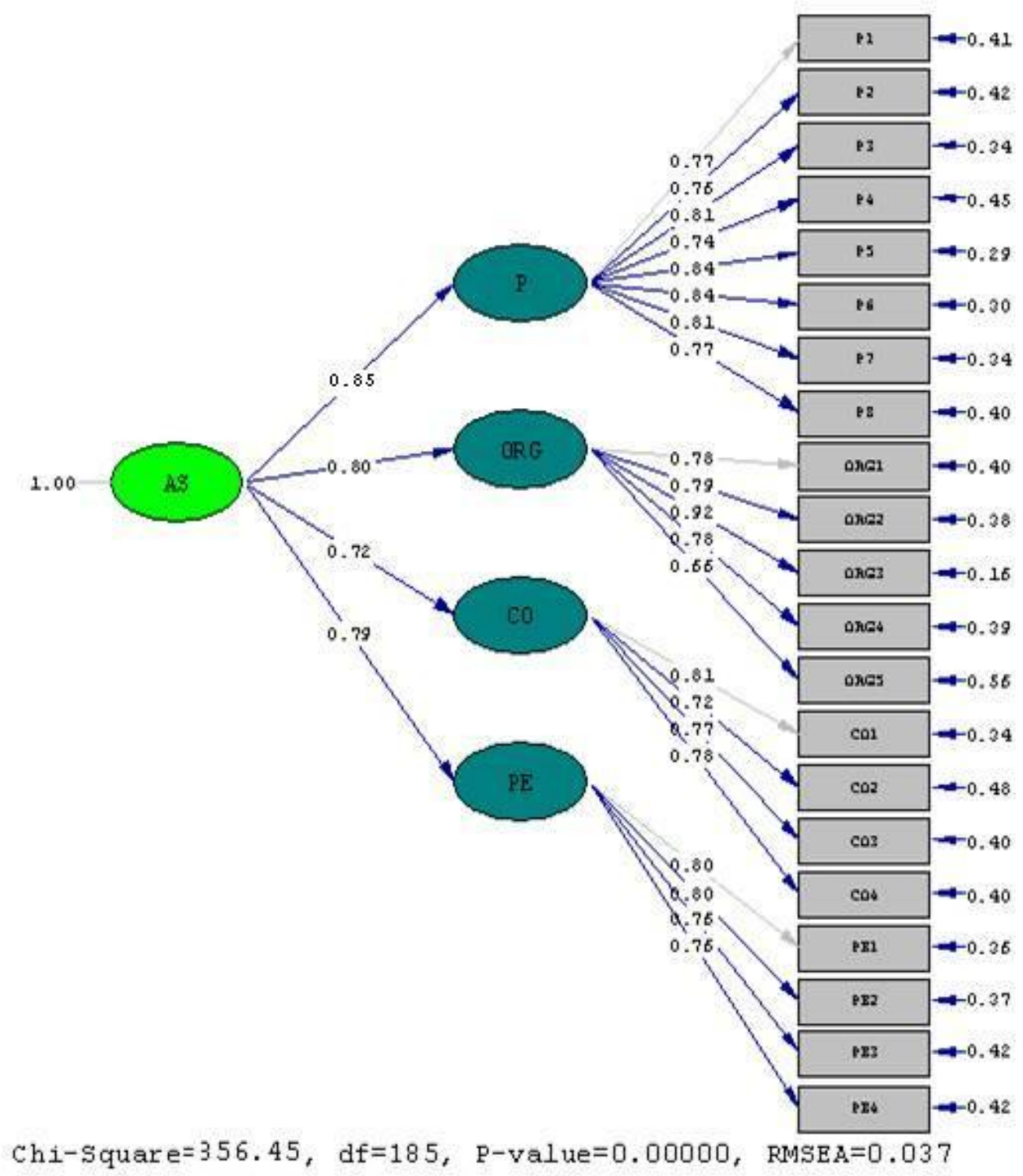

Figure 2. Standardized Solutions Model for AS

Figure (2) shows the extent each variable describes AS. The ranking of the variables is as follows: 1. Product, 2. Organization, 3. People, 4. Cooperation.

Also, the followings are the results of figure2:

The significant factors in Product are P5 and P6 with the same correlation coefficient of 84\%, which are "Compared to competitors, the time-to-market of new services and products is 
higher" and "Putting more effort into customer support than other competitors in the industry".

1. The significant factor in Organization is Org3 with the correlation coefficient of $92 \%$, which is "Organizational strategies and goals are communicated to all employees".

2. The significant factor in Cooperation is Co1 with the correlation coefficient of $81 \%$, which is "the preferring way to solve problems".

3. And the significant factor in People are Pe1 and Pe 2 with the same correlation coefficient of $80 \%$, which are "focusing the employees on organizational goals and success" and "the employee's compensation depends on the quality of their performance".

\subsubsection{Y model; Measurement Model of WO}

In next step we adopted confirmatory factor analysis for WO and its indicators in Lisrel 8.5 and eventually conducted path diagram of Y model as per Figure 3. We have tested Relationship between WO latents and its indicators. Fitness's indices in Table 8 shows good fitness of our X model, proving selected indicator are good representative for each dimension of WO. Also WO is defined as a higher-order construct which represents (a) Job uncertainty, (b) Job complexity, (c) Job demands, (d) Job control and (e) Skill variety. So our third hypothesis (H3) is supported.

Table 8. WO model fitness indices

\begin{tabular}{|c|c|}
\hline fitness indices & $\begin{array}{c}\text { Measure of } \\
\text { Index }\end{array}$ \\
\hline Chi-Square/df & 2.0505 \\
\hline P-value & 0.00012 \\
\hline $\begin{array}{c}\text { Root Mean Square Error of } \\
\text { Approximation (RMSEA) }\end{array}$ & 0.074 \\
\hline Goodness of Fit Index (GFI) & 0.93 \\
\hline Adjusted Goodness of Fit Index (AGFI) & 0.88 \\
\hline
\end{tabular}

Figure (3) shows the extent each variable describes AS. The ranking of the variables is as follows: 1.Job complexity, 2.Job uncertainty, 3. Job control, 4. Job demands, 5. Skill variety.

Also, the followings are the results of figure 3 :

1. The significant factor in Job uncertainty is JUN2 with the correlation coefficient of $86 \%$, which is "have to handle surprising or unpredictable situations". Also, JUN1 with the correlation coefficient of $82 \%$ is of great importance, which is "performing the tasks that are clearly defined".

2. The significant factor in Job complexity is JCM2 with the correlation coefficient of $88 \%$, which is "coming across problems that we have not encountered before".

3. The significant factor in Job demands is JDM1 with the correlation coefficient of $75 \%$, which is "requiring quick decisions in work".

4. The significant factor in Job control is JC1 with the correlation coefficient of 91\%, which is "allowing workers to decide the order in which things are done". 


\section{I Macrothink}

Business and Economic Research

ISSN 2162-4860 2013, Vol. 3, No. 1

5. And the significant factor in Skill variety is SV1 with the correlation coefficient of $73 \%$, which is "Similarity in the tasks that perform in a typical work day".

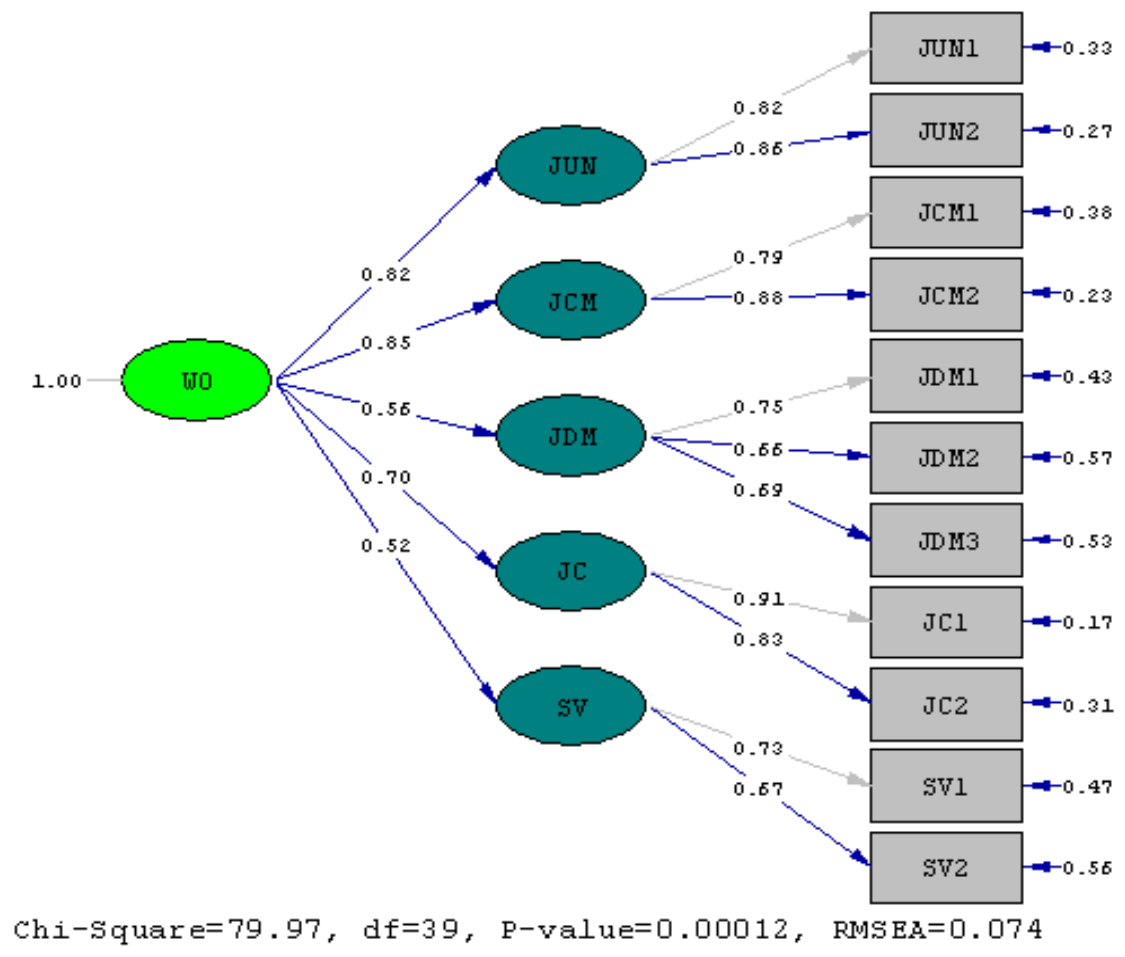

Figure 3. Standardized Solutions Model for WO

\subsubsection{Structural Model; the Effect of AS on WO}

For entering data gathered from questionnaires in SEM for investigating our main hypothesis, we define a new variable for every latent variable and use the mean of scored answers. So we define 10 variables (4 for AS and 5 for WO). In other words, we performed our Structural model applying 7 dimensions of AS and 4 component of WO.

As shown in Figure 4, AS can determine 33.64 percent $\left(0.58^{2}\right)$ of WO variances which is a significant role. Fitness's indices in Table 9 show good fitness of the Structural model. So our main hypothesis (H1) is supported. Also "Product" and "People" are fairly most important dimensions of AS and in the WO, "Job complexity" and "Job uncertainty" are fairly most important dimensions of WO.

Table 9. The Structural Model Fitness Indices

\begin{tabular}{|c|c|}
\hline fitness indices & $\begin{array}{c}\text { Measure of } \\
\text { Index }\end{array}$ \\
\hline Chi-Square/df & 1.3819 \\
\hline P-value & 0.00289 \\
\hline $\begin{array}{c}\text { Root Mean Square Error of } \\
\text { Approximation (RMSEA) }\end{array}$ & 0.044 \\
\hline Goodness of Fit Index (GFI) & 0.96 \\
\hline Adjusted Goodness of Fit Index (AGFI) & 0.93 \\
\hline
\end{tabular}




\section{Macrothink}

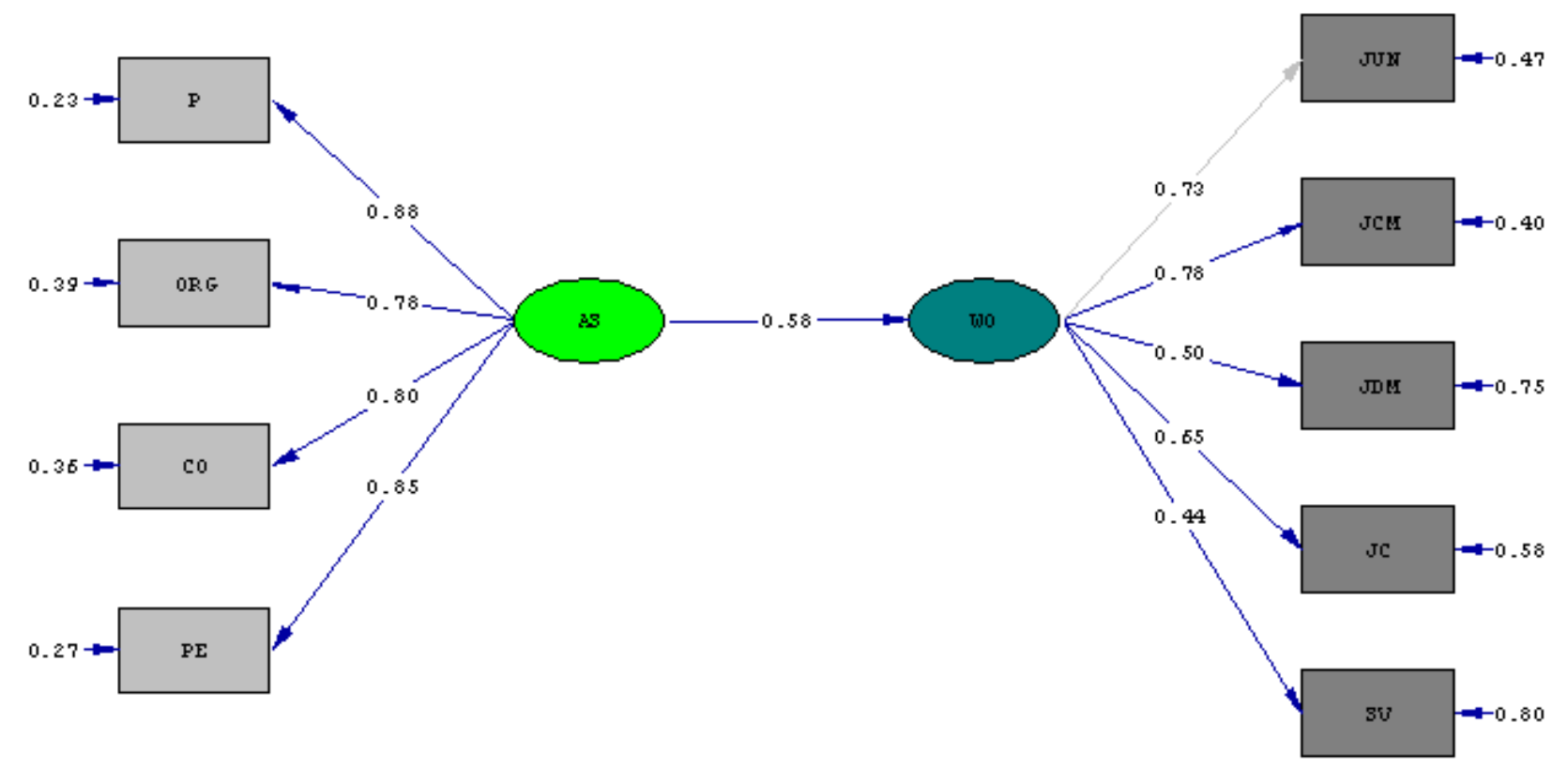

Chi-square=35.93, df=26, P-value=0.00289, RMSEA=0.044

Figure 4. Structural model: the effect of AS on WO

\section{Summary and Concluding Remarks}

This research intended to investigate the relationship between AS and WO by using SEM in the Iranian Textile Industry. For this investigation, first we studied in hand literature and extracted impressive criteria on AS and WO. Then we devised a questionnaire and distributed it to experts and professionals in five companies in the Iranian Textile Industry. At the end, we analyzed output from questionnaires by utilizing SEM. We have tested our proposed model in three steps: 1.AS: its latents and indicators; 2. WO: its latents and indicators; and 3.The effect of AS on WO.

This study has some limitations. First, we measured AS as independent variable which may differ in different industry and make it fairly difficult to generalize it. Second, we study perceived AS and WO rather than the reality.

In spite of the aforementioned limitations, there are important managerial implications obtained from the findings. According to research findings, AS is defined as a higher-order construct which represents (a) Product, (b) Organization, (c) Cooperation and (d) People. Also WO is defined as a higher-order construct which represents (a) Job uncertainty, (b) Job complexity, (c) Job demands, (d) Job control and (e) Skill variety. Finally, we found that AS will positively influence WO meaningfully. Also "Product" and "People" are fairly most important dimensions of AS and in the WO, "Job complexity" and "Job uncertainty" are fairly most important dimensions of WO.

Obtained results in this research is in a same direction in some aspects with other findings in different studies. For example, our results are supporting Sherehiy (2008), shown that there 
was a positive relationship between AS and WO in six small size enterprises (SMEs) in the USA. She stated that AS has a significant positive impact on WO.

Findings in this research are increasing our knowledge about relationship between AS and WO in textile industry. For future studies we suggest more empirical studies in different companies. Also we suggest that researchers consider relationships between AS and WO in textile industry with investigating key elements in environment (like supply, demand, and technology uncertainty).

\section{References}

Allworth, E., \& Hesketh, B. (1999). Construct-oriented biodata: Capturing change-related and contextually relevant future performance. International Journal of Selection and Assessment, 7(2), 97-111. http://dx.doi.org/10.1111/1468-2389.00110

Arteta, B. M., \& Giachetti, R. E. (2004). A measure of agility as the complexity of the enterprise system. Robotics and Computer-Integrated Manufacturing, 20(6), 495-503. http://dx.doi.org/10.1016/j.rcim.2004.05.008

Dawis, R. V., \& Lofquist, L. H. (1984). A psychological theory of work adjustment. Minneapolis: University of Minnesota Press.

Fay, D., \& Frese, M. (2001). The Concept of Personal Initiative: An Overview of Validity Studies. Human Performance, 14(1), 97-124. http://dx.doi.org/10.1207/S15327043HUP1401_06

Forsythe, C. (1997). Human Factors in Agile Manufacturing: a brief overview with emphasis on communications and information infrastructure. Human Factors and Ergonomics in Manufacturing, $7(1)$, $3-10$. http://dx.doi.org/10.1002/(SICI)1520-6564(199724)7:1<3::AID-HFM1>3.0.CO;2-7

Frese, M., Kring, W., Soose, A., \& Zempel, J. (1998). Personal Initiative at work: Differences between East and West Germany. Academy of Management Journal, 39(1), 37-63. http://dx.doi.org/10.2307/256630

Goldman, S. L., Nagel, R. N., \& Preiss, K., (1995). Agile Competitors and Virtual Organizations: Strategies for Enriching the Customer. New York: Van Nostrand Reinhold.

Gunasekaran, A. (1999). Agile manufacturing: a framework for research and development, International Journal of Production Economics, 62(1-2), 87-105. http://dx.doi.org/10.1016/S0925-5273(98)00222-9

Hackman, R. J., \& Oldham, G. R. (1975). Development of the job diagnostic survey. Journal of Applied Psychology, val. 60, pp: 159-170.

Jackson, M. C., \& Johansson, C. (2003). An agility analysis from a production system perspective. Integrated Manufacturing system, 14(6), 482-488. http://dx.doi.org/10.1108/09576060310491342

Karasek, R. A. (1979). Job demands, job decision latitude, and mental strain: Implications for 
job redesign. Administrative Science Quarterly. 24, 285-307. http://dx.doi.org/10.2307/2392498

Karasek, R. A., \& Theorell, T. (1990). Healthy work: stress, productivity and the reconstruction of working life. New York: Basic Books.

Kathuria, R., \& Partovi, F. Y. (1999). Workforce management practices for manufacturing flexibility. Journal of Operations Management, 18(1), 21-39. http://dx.doi.org/10.1016/S0272-6963(99)00011-X

Lin, C.-T., Chiu H, \& Chu, P.-Y. (2006). Agility index in the supply chain .International Journal of Production Economics, 100: 285-299. http://dx.doi.org/10.1016/j.ijpe.2004.11.013

Moon, J-W., \& Kim, Y-G. (2001), Extending the TAM for a World-Wide-Web context, Information and Management, 38, 217-30. http://dx.doi.org/10.1016/S0378-7206(00)00061-6

Morgeson, F. P., \& Campion, M. A. (2003). Work design in W. C. Borman, D. R. Ilgen and R. J. Klimoski (Eds.), Handbook of Psychology: Industrial and Organizational Psychology, 12, 423-452.

Ngai, E. W. T., Poon, J. K. L., \& Chan, Y. H. C. (2007). Empirical examination of the adoption of WebCT using TAM, Computers and Education, 48, 250-67. http://dx.doi.org/10.1016/j.compedu.2004.11.007

Ohly, S., Sonnentag, S., \& Pluntke, F. (2006). Routinization, work characteristics, and the relationship with creative and proactive behaviours. Journal of Organizational Behavior, 27, 257-279. http://dx.doi.org/10.1002/job.376

Parker, S., \& Wall, T. (1998). Job and Work Design: Organizing Work to Promote Well-Being and Effectiveness. Thousand Oaks: Sage Publications.

Parker, S., Wall, T. \& Cordery, J. (2001). Future work design research and practice: Towards an elaborated model of work design. Journal of Occupational and Organizational psychology, 74, 413-440. http://dx.doi.org/10.1348/096317901167460

Plonka, F. S. (1997). Developing a Lean and Agile Work Force. Human Factors and $\begin{array}{llll}\text { Ergonomics in } \quad \text { Manufacturing, } & 7(1),\end{array}$ http://dx.doi.org/10.1002/(SICI)1520-6564(199724)7:1<11::AID-HFM2>3.0.CO;2-J

Pulakos, E. D., Schmitt, N., Dorsey, D. W., Arad, S., Hedge, J. W., \& Borman, W. C. (2002). Predicting adaptive performance: Further tests of a model of adaptability. Human Performance, 15(4), 299-323. http://dx.doi.org/10.1207/S15327043HUP1504_01

Sharifi, H. \& Z. Zhang. (1999). A methodology for achieving agility in manufacturing organizations: An introduction. International Journal of Production Economics, 62, 7-22. http://dx.doi.org/10.1016/S0925-5273(98)00217-5

Sherehiy, Bohdana. (2008). Relationship between Agility Strategy, Work Organization and Workforce Agility. PhD Thesis, University of Louisville, USA. 


\section{Macrothink}

Business and Economic Research ISSN 2162-4860 2013, Vol. 3, No. 1

Sherehiy, B., Karwowski, W., \& Layer, J. K. (2007). A review of enterprise agility: Concepts, frameworks, and attributes. International Journal of Industrial Ergonomics, 37, 445-460. http://dx.doi.org/10.1016/j.ergon.2007.01.007

Sumukadas, N., \& Sawhney, R. (2004). Workforce agility through employee involvement. Lie Transactions, 36(10), 1011-1021.

Tsourveloudis, N. C. \& Valavanis, K.P. (2002). On the measurement of enterprise agility. Journal of Intelligent and Robotic Systems, 33(3), 329-342. http://dx.doi.org/10.1023/A:1015096909316

Wall, T. D., \& Martin, R. (1987). Job and work design. In C. L. Cooper and I. T. Robertson (Eds.), International review of industrial and organizational psychology. Oxford, England: John Wiley and Sons. 61-91.

Walton, R. E., \& Susman, G. E., (1987). People policies for the new machines. Harvard Business Review, March-April, 98-106.

Yaghoubi, N. M. \& Rahat Dahmardeh, M. (2010). Analytical approach to effective factors on organizational agility. Journal of Basic and Applied Scientific Research, 1(1), 76-87.

Yusuf, Y., \& Adeleye, E. O. (2002). A comparative study of lean and agile manufacturing with related survey of current practices in the UK. International Journal of Production Research, 40(17), 4545 -4562. http://dx.doi.org/10.1080/00207540210157141

Yusuf, Y., Sarhadi, M., \& Gunasekaran, A. (1999). Agile manufacturing: The drivers, concepts and attributes. International Journal of Production Economics, 62(1-2), 33-43. http://dx.doi.org/10.1016/S0925-5273(98)00219-9

\section{Appendix A}

Respondents are asked to rate the extent or degree of current practice of the following items on a five-point Likert scale with $1=$ "strongly disagree" to $5=$ "strongly agree".

Product (P) (Sherehiy, 2008; Lin et al., 2006; Jackson and Johansson, 2003; Tsourveloudis and Valavanis, 2002; Yusuf and Adeleye, 2002; Sharifi and Zhang, 1999; Yusuf et al., 1999; Goldman et al., 1995).

- $\quad$ P1 - My company looks for opportunities to add new profitable services or other values to our products.

- $\quad$ P2 - My company looks for opportunities to customize our products.

- $\quad$ P3 - Quality in my company is measured through customer satisfaction.

- $\quad$ P4- My company's products can be easily customized for an individual customer.

- $\quad$ P5- Compared to competitors, the time-to-market of my company's new services and products is higher. 


\section{Macrothink}

Business and Economic Research ISSN 2162-4860 2013, Vol. 3, No. 1

- $\quad$ P6- My company puts more effort into customer support than our competitors in the industry.

- $\quad$ P7- My company focuses on selling standard products.

- $\quad$ P8 - My company adds value to products by providing information and service to our customers.

Organization (Org) (Sumukadas and Sawhney, 2004; Arteta and Giachetti, 2004; Jackson and Johansson, 2003; Tsourveloudis and Valavanis, 2002; Yusuf et al., 1999; Sharifi and Zhang, 1999; Goldman et al., 1995).

- $\quad$ Org1- My company is effective at meeting changing goals and objectives.

- $\quad$ Org 2-In my company, the change is recognized as an opportunity.

- $\quad$ Org 3- Organizational strategies and goals are communicated to all employees.

- $\quad$ Org 4- In my company, it is difficult to move workers between different tasks (reversed coded).

- $\quad$ Org 5- In my company, it is easy to reconfigure physical and human resources to meet changed customer demands.

Cooperation (Co) (Sherehiy, 2008; Lin et al., 2006; Sumukadas and Sawhney, 2004; Jackson and Johansson, 2003; Sharifi and Zhang, 1999; Kathuria and Partovi, 1999).

- $\quad$ Co 1 - In my company, cooperation is the preferred way to solve problems.

- $\quad$ Co 2- My company encourages co-operation among its workers.

- $\quad$ Co 3- My company establishes long-term contracts with major suppliers.

- Co 4- My company's products/services are designed in cooperation with the customers and suppliers.

People (Pe) (Sumukadas and Sawhney, 2004; Jackson and Johansson, 2003; Kathuria and Partovi, 1999; Sharifi and Zhang, 1999; (Goldman et al., 1995; Yusuf et al., 1999).

- $\quad$ Pe 1- In my company, the employees are focused on organizational goals and success.

- $\quad$ Pe 2- In my company, the employee's compensation depends on the quality of their performance.

- $\quad$ Pe 3- In my company, the number of cross-trained workers is high.

- $\quad$ Pe 4- In my company, the employees at all levels are encouraged to participate in decision making process.

Job uncertainty (JUN) (Pulakos et al., 2002; Allworth and Hesketh, 1999).

- $\quad$ JUN 1- In my job, the tasks I perform are clearly defined.

- $\quad$ JUN 2- In my job, I have to handle surprising or unpredictable situations. 


\section{Macrothink}

Business and Economic Research

ISSN 2162-4860 2013, Vol. 3, No. 1

Job complexity (JCM) (Ohly et al., 2006; Pulakos et al., 2002; Fay and Frese, 2001; Frese et al., 1998).

- $\quad$ JCM 1- In my job, I have to deal with problems which are difficult to solve.

- $\quad$ JCM 2 - In my job, I come across problems that I have not encountered before.

Job demands (JDM) (Sherehiy, 2008; Plonka, 1997).

- JDM 1- My work requires quick decisions.

- $\quad$ JDM 2- My job requires working very hard.

- $\quad$ JMM3 - I do not have enough time to get the job done.

Job control (JC) (Yusuf et al., 1999; Kathuria and Partovi, 1999; Plonka, 1997; Karasek and Theorell, 1990; Walton and Susman, 1987; Dawis and Lofquist, 1984).

- $\quad$ JC 1- My job allows me to decide the order in which things are done.

- $\quad$ JC 2- How much influence do you have on the amount of work assigned to you?

Skill variety (SV) (Pulakos et al., 2002; Plonka, 1997; Karasek, 1979; Forsythe, 1997; Karasek and Theorell, 1990; Hackman and Oldham, 1975).

- $\quad$ SV 1 - The tasks I perform in a typical work day are very similar (reversed coded).

- $\quad$ SV 2- To what extent do you use all your knowledge and skills at work?

\section{Copyright Disclaimer}

Copyright reserved by the author(s).

This article is an open-access article distributed under the terms and conditions of the Creative Commons Attribution license (http://creativecommons.org/licenses/by/3.0/). 